\title{
Cloning and Expression of the Clostridium thermohydrosulfuricum $\alpha$-Amylase-pullulanase Gene in Escherichia coli
}

\author{
By HANNES MELASNIEMI* AND MARJA PALOHEIMO \\ Research Laboratories, Alko Ltd, POB 350, SF-00101, Helsinki, Finland
}

(Received 28 December 1988; revised 27 February 1989; accepted 20 March 1989)

\begin{abstract}
An $\alpha$-amylase-pullulanase gene from Clostridium thermohydrosulfuricum DSM 3783 was cloned in Escherichia coli on a $7.0 \mathrm{~kb} E c o \mathrm{RI}$ fragment using a $\lambda$ vector. The gene produced, from an indigenous promoter, active thermostable $\alpha$-amylase-pullulanase, seemingly mostly a soluble intracellular enzyme in $E$. coli. Gel filtration separated the active enzyme produced into three peaks, each having both $\alpha$-amylase and pullulanase activities. Immunoblotting after SDSPAGE revealed more than ten $\alpha$-amylase-pullulanase specific polypeptides; the biggest of these had an $M_{\mathrm{r}}$ of about 165000 , whereas the smallest enzymically active polypeptide had an $M_{\mathrm{r}}$ of about 100000 . Despite the marked degeneration of its constituent polypeptides, the apparent temperature optimum of the enzyme $\left(80-85^{\circ} \mathrm{C}\right)$ was only some $5^{\circ} \mathrm{C}$ lower and the heat stability the same as that of the extracellular $\alpha$-amylase-pullulanase produced by the native host. Oligonucleotide probes prepared according to the $\mathrm{NH}_{2}$-terminal amino acid sequences of the enzyme and its satellite polypeptide (a polypeptide associated with the extracellular enzyme of the native host) hybridized to different regions of the $7.0 \mathrm{~kb}$ DNA insert.
\end{abstract}

\section{INTRODUCTION}

Starch is composed of glucose units linked through $\alpha-1,4$ linkages to form chains of varying length. Most of the chains are branched through $\alpha-1,6$ linkages, the number of which amounts to about $3-4 \%$ of the total linkages. Pullulan is also composed of glucose, but in this polymer every third linkage between the constituent glucose units is $\alpha-1,6$, the rest of the linkages being $\alpha-1,4 . \alpha-$ Amylases (EC 3.2.1.1) attack the $\alpha-1,4$ linkages in starch, whereas pullulanases (EC 3.2.1 .41) attack the $\alpha-1,6$ linkages in pullulan and starch (Fogarty \& Kelly, 1979). However, the $\alpha-$ amylases from Thermoactinomyces vulgaris (Shimizu et al., 1978) and Bacillus stearothermophilus (Suzuki \& Imai, 1985) cleave $\alpha-1,4$ bonds in starch and pullulan. The exo-amylase from Bacillus sp. (Suzuki et al., 1987) cleaves $\alpha-1,4$ linkages in starch and pullulan, and also $\alpha-1,6$ linkages in starch. Pullulanase $/ \alpha$-amylase enzymes cleaving $\alpha-1,6$ linkages in pullulan as well as $\alpha-1,4$ and $\alpha-$ 1,6 linkages in starch have recently been described from Bacillus subtilis (Takasaki, 1987), Thermoanaerobium brockii (Coleman et al., 1987) and Thermoanaerobium sp. (Plant et al., 1987).

Clostridium thermohydrosulfuricum, an obligately anaerobic thermophile, also produces a thermostable and thermoactive enzyme having both $\alpha$-amylase and pullulanase activities (Melasniemi, 1987b, 1988). However, the amount of enzyme activity produced is rather low (Melasniemi, 1987a) and in addition the bacterium has complex nutritional requirements (Wiegel et al., 1979). By using recombinant DNA techniques, proteins which are of interest, but obtained with difficulty, can be produced in alternative host organisms. The debranching enzyme of $T$. brockii (Coleman et al., 1987) and a pullulanhydrolase from B. stearothermophilus producing not only panose but also maltose and glucose (Kuriki et al., 1988) have recently been cloned. In the present paper the cloning and expression of the C. thermohydrosulfuricum $\alpha-$ amylase-pullulanase gene in Escherichia coli are reported. 


\section{METHODS}

Bacterial strains, phages, plasmids and culture conditions. C. thermohydrosulfuricum DSM 3783 (E 101-69) was grown as described previously (Melasniemi, 1987a) for $20 \mathrm{~h}$ in 21 of medium containing $2 \%(\mathrm{w} / \mathrm{v})$ glucose. EcoRIdigested dephosphorylated $\lambda$ gt 11 vector DNA and $E$. coli host strains $\mathrm{Y} 1090\left(\mathrm{r}^{-}\right)$and $\mathrm{Y} 1089\left(\mathrm{r}^{-}\right)$are contained in the Protoclone $\lambda$ gt11 system (Promega). The host strains are restriction-minus derivatives of strains Y1090 and Y1089, whose use with $\lambda$ gt1 1 has been described in detail by Huynh et al. (1985).

Plasmids pUC18 and pUC19, differing from each other only in the orientation of their polylinkers, were used for sub-cloning in E. coli JM109 (Yanisch-Perron et al., 1985). The polylinkers of the plasmids as well as the unique $E c o R I$ site of $\lambda$ gtl1 are located within the $\beta$-galactosidase gene adjacent to its promoter, enabling recombinant clones having inserts in these cloning sites to be recognized by the $\mathrm{X}$-gal test.

E. coli $\mathrm{JM} 109$ was grown at $37^{\circ} \mathrm{C}$ for $16-18 \mathrm{~h}$ on Luria-Bertani plates (Maniatis et al., 1982) containing ampicillin $\left(50-100 \mu \mathrm{g} \mathrm{ml}^{-1}\right)$ or in the same liquid medium with vigorous shaking.

Isolation of DNA. Chromosomal DNA was isolated from $C$. thermohydrosulfuricum by the phenol method of Amundsen \& Neville (1979) modified as follows. Cells ( $5 \mathrm{~g}$, wet wt) were incubated for $15 \mathrm{~min}$ at $37^{\circ} \mathrm{C}$ in $25 \mathrm{ml}$ of $50 \mathrm{mM}$-Tris $/ \mathrm{HCl} \mathrm{pH} 8.0$ containing $10 \%(\mathrm{w} / \mathrm{v})$ sucrose, $50 \mathrm{~mm}$-EDTA and lysozyme $\left(5 \mathrm{mg} \mathrm{ml}^{-1}\right)$. Sarkosyl was added to $2 \%(\mathrm{w} / \mathrm{v})$ and the incubation was continued for $30 \mathrm{~min}$ at $65^{\circ} \mathrm{C}$. The isolated DNA was treated with proteinase $\mathrm{K}$ and extracted with phenol and chloroform. The solution of the DNA in TE (10 mM-Tris/ $\mathrm{HCl} \mathrm{pH} 8.0$, $0 \cdot 1 \mathrm{~mm}$-EDTA) was adjusted to a refractive index of 1.3804 with $\mathrm{CsCl}$ and centrifuged at 40000 r.p.m. for $20 \mathrm{~h}$ at $20{ }^{\circ} \mathrm{C}$ in a Kontron TFT 50.13 rotor with full tubes. The DNA was recovered from the bottom fractions and dialysed against TE. $\lambda$ DNA was extracted from DNAase- and RNAase-treated polyethylene-glycol-precipitated phage particles (Maniatis et al., 1982). Plasmid DNA was isolated by the method of Birnboim \& Doly (1979). For rapid screening of clones the method of Holmes \& Quigley (1981) was used.

DNA manipulations. A buffer containing $6 \mathrm{~mm}-\mathrm{Tris} / \mathrm{HCl} \mathrm{pH} \mathrm{7.9,} 50 \mathrm{~mm}-\mathrm{NaCl}, 6 \mathrm{~mm}-\mathrm{MgCl}_{2}$ and $6 \mathrm{mM}-\beta-$ mercaptoethanol was used for all restriction enzymes except $E c o$ RI, for which $0 \cdot 1 \mathrm{vol}$. $1 \mathrm{M}-\mathrm{Tris} / \mathrm{HCl} \mathrm{pH} 7.6 \mathrm{was}$ added to the buffer. Analysis of restriction fragments and restriction mapping were done as described by Maniatis et al. (1982). For transformation of $E$. coli the method of Hanahan (1985) was used. Restriction enzymes, T4 DNA ligase and DNA standards were from Boehringer Mannheim.

Cloning and sub-cloning. EcoRI-digested chromosomal DNA was fractionated by sucrose density gradient centrifugation (Maniatis et al., 1982). Fragments $2-9 \mathrm{~kb}$ in size were pooled and ligated to the EcoRI site of $\lambda \mathrm{gt} 11$ DNA. The DNA was packed in vitro into $\lambda$ particles by using Packagene (Promega) packaging extracts. Positive plaques on a lawn of $\mathrm{Y} 1090\left(\mathrm{r}^{-}\right)$were screened by using a rabbit $\alpha$-amylase-pullulanase antiserum essentially as described by Huynh et al. (1985). The immunocomplexes were visualized by using goat anti-rabbit IgG horseradish peroxidase conjugate (Bio-Rad) together with the chromogenic substrate 3-amino-9-ethylcarbazole (Sarvas \& Nurminen, 1985). Screening for enzyme activity was done by overlaying the plates with $5 \mathrm{ml}$ of $0.8 \%$ melted agar in $0.2 \mathrm{M}$-sodium acetate pH 5.2 containing $0.05 \%$ soluble starch (Merck 1252) and $2 \mathrm{mM}^{-\mathrm{CaCl}} \mathrm{Cl}_{2}$, incubating for $16 \mathrm{~h}$ at $55^{\circ} \mathrm{C}$ and staining with iodine vapour. Several positive clones were amplified and concentrated phage stocks were prepared by polyethylene glycol precipitation (Maniatis et al., 1982). Recombinant $\lambda$ DNA extracted from samples of the stocks was digested with EcoRI and the sizes of the inserts were analysed. Y1089 $\left(\mathrm{r}^{-}\right)$was lysogenized with recombinant phage (Huynh et al., 1985) and phage DNA was prepared from induced cells. The insert was excised by $E c o$ RI, separated from the $\lambda$ arms by preparative agarose gel electrophoresis and sub-cloned in the EcoRI site on the polylinker of the pUC plasmids.

Oligonucleotide hybridization. Knowing the $\mathrm{NH}_{2}$-terminal amino acid sequences of the extracellular enzyme from the native host (Melasniemi, 1988) and its satellite polypeptide (H. Melasniemi, unpublished) 27-mer oligonucleotide mixtures complementary to all possible codon combinations for each of the $\mathrm{NH}_{2}$-terminal sequences were synthesized using a 381 A DNA Synthesizer (Applied Biosystems). In the case of the enzyme probe the mixture contained one perfectly matching oligonucleotide species out of a total of 36864 species, in the case of the satellite protein probe one out of 512. The oligonucleotides were labelled with $[\gamma-32 \mathrm{P}] \mathrm{ATP}$ using polynucleotide kinase (Maniatis et al., 1982). Hybridization was done at $60{ }^{\circ} \mathrm{C}$ directly in a dried $0.8 \%$ agarose gel (Miyada \& Wallace, 1987) with restriction fragments of the sub-cloned insert resolved on the gel. To eliminate unspecific binding the gels were washed with $0.9 \mathrm{M}-\mathrm{NaCl}$ in $90 \mathrm{mM}$-sodium citrate $\mathrm{pH} 7.0$ for a total of $2 \mathrm{~h}$ at room temperature, $5 \mathrm{~min}$ at $68^{\circ} \mathrm{C}$ and finally for $15 \mathrm{~min}$ at $45^{\circ} \mathrm{C}$.

Preparation of cell-free extracts and localization of the enzyme. Transformed JM109 cultures (200 ml) were centrifuged $(10000 \mathrm{~g}, 10 \mathrm{~min})$, and the cells were resuspended in $20 \mathrm{~mm}$-sodium acetate $\mathrm{pH} 5.6$ to $25 \mathrm{ml}$ and passed four times through a French pressure cell (Aminco) at $4{ }^{\circ} \mathrm{C}$ using a pressure of about $100 \mathrm{MPa}$. Soluble and particulate fractions were separated by ultracentrifugation $\left(165000 \mathrm{~g}, 90 \mathrm{~min}\right.$, at $\left.4^{\circ} \mathrm{C}\right)$ and the particulate pellet was resuspended in the same volume of the buffer. Outer and inner membrane fractions were obtained from the crushed cells as described by Smit et al. (1975), except that a protease inhibitor cocktail of phenylmethylsulphonyl fluoride, benzamidine/ $\mathrm{HCl}$ and $\mathrm{N}$-p-tosyl-L-lysine chloromethyl ketone (each $1 \mathrm{mM}$ ) and pepstatin A (10 $\mu \mathrm{M})$ was included in all solutions, and possibly unbroken cells were separated by centrifuging for $20 \mathrm{~min}$ at $1200 \mathrm{~g}$. 
Periplasmic proteins were released by osmotic shock (Neu \& Heppel, 1965) and by a lysozyme/EDTA treatment, in which centrifuged cells were resuspended in $10 \mathrm{~mm}$-Tris $/ \mathrm{HCl}$ pH 8.0 containing $1 \mathrm{~mm}$-EDTA, $0.5 \mathrm{M}$-sucrose and lysozyme $\left(5 \mathrm{mg} \mathrm{ml}^{-1}\right)$, incubated for $15 \mathrm{~min}$ at $37^{\circ} \mathrm{C}$ and diluted with an equal volume of water, after which the spheroplasts were separated by centrifugation $(10000 \mathrm{~g}, 6 \mathrm{~min})$. The periplasmic and intracellular marker enzymes, alkaline phosphatase and glucose-6-phosphate dehydrogenase, respectively, were assayed as described by Malamy \& Horecker (1964).

Binding of $\left[{ }^{14} \mathrm{C}\right]$ starch. Samples boiled for $2.5 \mathrm{~min}$ in the sample buffer were resolved on a $10 \%(\mathrm{w} / \mathrm{v})$ SDS-PAGE gel (Laemmli, 1970) and blotted onto nitrocellulose essentially as described by Sarvas \& Nurminen (1985). The filters were gently shaken, first for $2 \mathrm{~h}$ at room temperature in $50 \mathrm{mM}-\mathrm{Tris} / \mathrm{HCl} \mathrm{pH} 8.0$ containing $150 \mathrm{mM}-\mathrm{NaCl}$ and $5 \%\left(\mathrm{w} / \mathrm{v}\right.$, dry wt) skim milk for quenching, and then for $16 \mathrm{~h}$ on ice with $35 \mu \mathrm{Ci}(1295 \mathrm{kBq})$ of $\left[\mathrm{U}-{ }^{14} \mathrm{C}\right] \mathrm{starch}$ (New England Nuclear) in $10 \mathrm{ml}$ of $100 \mathrm{~mm}$-sodium acetate $\mathrm{pH} 5.6$ containing $2 \mathrm{~mm}-\mathrm{CaCl}_{2}, 0 \cdot 1 \mathrm{mM}-\mathrm{EDTA}$ and $50 \mathrm{mM}-\mathrm{NaCl}$. The filters were washed with ice-cold water, dried and exposed to a Kodak X-Omat XR film.

Enzyme and protein assays. $\alpha$-Amylase and pullulanase activities were assayed by measuring the amount of reducing sugar released in $15 \mathrm{~min}$ from amylose or pullulan as described previously (Melasniemi, 1987a), except that a temperature of $80^{\circ} \mathrm{C}$ and $\mathrm{CaCl}_{2}$ concentration of $10 \mathrm{mM}$ was used. One unit of activity is defined as the amount of enzyme releasing $1 \mathrm{nmol}$ reducing sugar $\mathrm{min}^{-1}$ in the assay. Protein was measured by the Bio-Rad assay using ovalbumin as a standard.

\section{RESULTS AND DISCUSSION}

\section{Cloning of the amylase gene and its promoter region}

The $C$. thermohydrosulfuricum genomic library in $\lambda \mathrm{gt} 11$ had a titre of $9 \times 10^{5}$ p.f.u. per $\mu \mathrm{g}$ of packaged DNA and it contained about $85 \%$ recombinant phage particles, approximately $1 \%$ of which caused the production of $\alpha$-amylase-pullulanase. Screening the plates first immunologically and subsequently for enzyme activity revealed roughly equal numbers of positive clones, most of which were detected by both methods. Because the immunological method gave clearer signals and required no replication of the plates, it was used to purify several positive plaques. All purified $\lambda$ clones had the same $7.0 \mathrm{~kb}$ insert, which was subsequently sub-cloned into the EcoRI site of pUC18 and pUC19 to give the plasmids pALK351 and pALK353. The restriction map of the cloned fragment is given in Fig. 1. The restriction sites shown are also found in the oppositely oriented polylinkers of the pUC plasmids.

Both $\lambda$ gt 11 and the pUC vectors used are able to express genes inserted in the right reading frame as hybrid proteins from the $\beta$-galactosidase promoter upstream of the cloning sites. However, the $\alpha$-amylase-pullulanase gene is probably transcribed from a $C$. thermohydrosulfuricum promoter on the $7.0 \mathrm{~kb}$ insert, because the amount of enzyme activity produced by the recombinant pUC plasmids was not affected by changing the orientation of the insert.

\section{Position and orientation of the amylase gene}

The extracellular $\alpha$-amylase-pullulanase of $C$. thermohydrosulfuricum DSM 3783 occurs in the culture medium in tight, apparently equimolar association with a polypeptide $\left(M_{\mathrm{r}} 24000\right)$, the $\alpha$-amylase-pullulanase satellite polypeptide (Melasniemi, 1988). The synthesized 27-mer oligonucleotide probes for the DNA sequences encoding the $\mathrm{NH}_{2}$-terminal ends of the enzyme and the satellite protein hybridized specifically to the $1.2 \mathrm{~kb} \mathrm{BamHI}-P s t \mathrm{I}$ fragment and the $2.6 \mathrm{~kb} S p h \mathrm{I}-E c o$ RI fragment of pALK 353 , respectively (Fig. 1).

The $0.8 \mathrm{~kb}$ Eco RI-BamHI fragment from pALK353 (Fig. 1) was deleted by cutting the polylinker and the insert with BamHI and religating to obtain the plasmid pALK355. The insert of this plasmid still has a coding capacity in excess of that required for a polypeptide of the same size as the highest estimate for the subunit of the enzyme of the native host. This deletion had no effect on the amount of activity produced. In contrast, when the $2.6 \mathrm{~kb} S p h \mathrm{I}-E c o \mathrm{RI}$ fragment was deleted from pALK351 (Fig. 1) by cutting with SphI and religating, no activity was produced. Together with the hybridization data, these results indicate that the promoter region and the $5^{\prime}$-end of the $\alpha$-amylase-pullulanase structural gene are located on the $1.2 \mathrm{~kb} \mathrm{BamHI}-$ PstI fragment of pALK 353 and that the gene extends onto the $2.6 \mathrm{~kb}$ SphI-EcoRI fragment. 


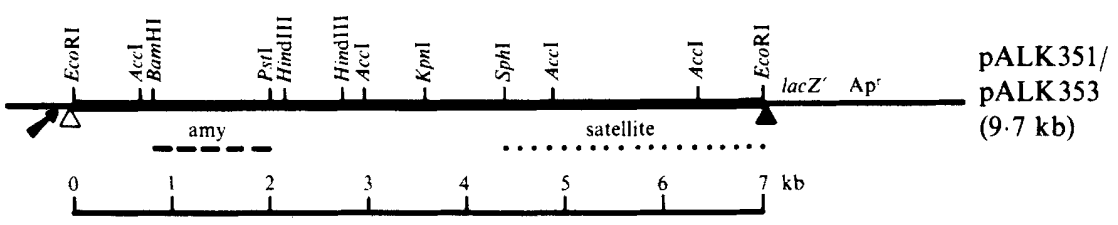

Fig. 1. Restriction map of the 7.0 $\mathrm{kb}$ C. thermohydrosulfuricum DNA fragment sub-cloned in the EcoRI site of pUC18 and pUC19 plasmids to obtain the plasmids pALK351 and pALK353 respectively. $\square$, Insert DNA; - , vector DNA; $\boldsymbol{A}$, polylinker of pALK351; $\triangle$, polylinker of pALK 353; arrow, lac Z' promoter. The plasmid pALK 355 was obtained from pALK 353 by deleting the EcoRI-BamHI fragment adjacent to the polylinker. The regions hybridizing with the $\alpha$-amylase-pullulanase and the satellite polypeptide probes are indicated by --- and $\cdots$ respectively.

\section{Localization of the enzyme in E. coli}

During growth of $E$. coli JM109 carrying pALK355, pullulanase and $\alpha$-amylase activities were proportional to the cell mass and reached $2 \cdot 1$ and $0.64 \mathrm{kU} \mathrm{ml}^{-1}$, respectively, after $18 \mathrm{~h}$. This is only slightly more than is produced by the original host (Melasniemi, 1987a). Only about $2 \%$ of the total enzyme activity was found in the culture medium. No activity was released by washing the cells with $10 \mathrm{~mm}$-Tris/ $\mathrm{HCl} \mathrm{pH} \mathrm{8.0,} \mathrm{and} \mathrm{intact} \mathrm{washed} \mathrm{cells} \mathrm{showed} \mathrm{less} \mathrm{than} 1 \%$ of the total activity. The bulk of the enzyme activity $(98 \%)$ was manifested only after complete disintegration of the cells.

About $85 \%$ of the activity of the cell-free extracts was found in the soluble fraction and about $15 \%$ sedimented on ultracentrifugation. However, when possible association of the sedimented enzyme with outer or inner membrane vesicles was tested by separating the vesicles by sucrose density gradient ultracentrifugation no amylase activity was found in the vesicular fractions; instead the activity was found exclusively in the top fractions of the gradients. The possibility of a periplasmic location was tested. Spheroplasting the cells by lysozyme/EDTA released $80 \%$ of the periplasmic marker enzyme alkaline phosphatase, less than $1 \%$ of the intracellular marker enzyme glucose-6-phosphate dehydrogenase, and less than $3 \%$ of $\alpha$-amylase-pullulanase. Osmotic shock released more than $75 \%$ of the alkaline phosphatase, slightly less than $3 \%$ of the glucose-6-phosphate dehydrogenase and about $10 \%$ of the $\alpha$-amylase-pullulanase.

The $\alpha$-amylase-pullulanase produced by $C$. thermohydrosulfuricum DSM 3783 is bound to the cell surface or is released into the medium, depending on the culture conditions (Melasniemi, 1987 a). The present results are most consistent with the idea that the enzyme is produced in $E$. coli as a soluble intracellular protein. Some affinity for the cytoplasmic membrane is suggested by both the sedimentation of a part of the enzyme from homogenates and the slightly higher release of the amylase than of cytoplasmic glucose-6-phosphate dehydrogenase from the cells during the spheroplasting and osmotic shock treatments, which may cause some damage to the cytoplasmic membranes.

\section{Degeneracy of the amylase produced in E. coli}

Gel filtration of the soluble portion of a cell-free extract of JM109 harbouring pALK355 resolved the $\alpha$-amylase-pullulanase activity into three peaks (I-III), each showing both $\alpha$ amylase and pullulanase activities in an approximately $1 / 3$ ratio (Fig. 2). Approximate $M_{\mathrm{r}}$ values of (I) 330000 , (II) 245000 and (III) 202000 were obtained from a linear calibration curve established by using thyroglobulin $\left(M_{\mathrm{r}} 669000\right)$, apoferritin $\left(M_{\mathrm{r}} 443000\right)$, catalase $\left(M_{\mathrm{r}} 232000\right)$ and aldolase $\left(M_{\mathrm{r}} 158000\right)$ as standards. The $M_{\mathrm{r}}$ of the enzyme in peak III may, however, be somewhat over-estimated, since deviations from linearity were observed with proteins smaller than aldolase, the smallest protein used for calibration.

Over ten distinct $\alpha$-amylase-pullulanase specific bands were resolved by immunoblotting from cells carrying pALK 355 (Fig. 3). The authenticity of the bands was confirmed by specific binding of $\left[{ }^{14} \mathrm{C}\right]$ starch by all of the immunologically detected major bands above $M_{\mathrm{r}} 40000$ (results not shown). 


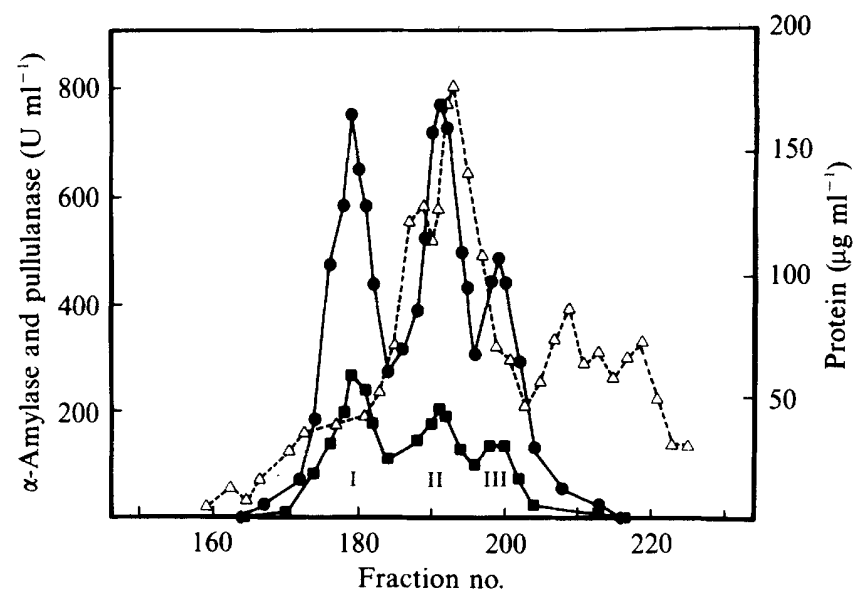

Fig. 2. Gel filtration on combined Superose 12 and 6 columns of the $\alpha$-amylase-pullulanase produced in $E$. coli. A sample $(200 \mu \mathrm{l})$ from the soluble fraction of a cell-free extract from JM109 carrying pALK 355 was run at room temperature through consecutive Superose 12 and 6 columns (Pharmacia) in $100 \mathrm{~mm}$ sodium acetate pH 5.6 at a rate of $6 \mathrm{ml} \mathrm{h}^{-1}$ and $150 \mu \mathrm{l}$ fractions were collected. $\square, \alpha$-Amylase activity; , pullulanase activity; $\triangle$, protein.

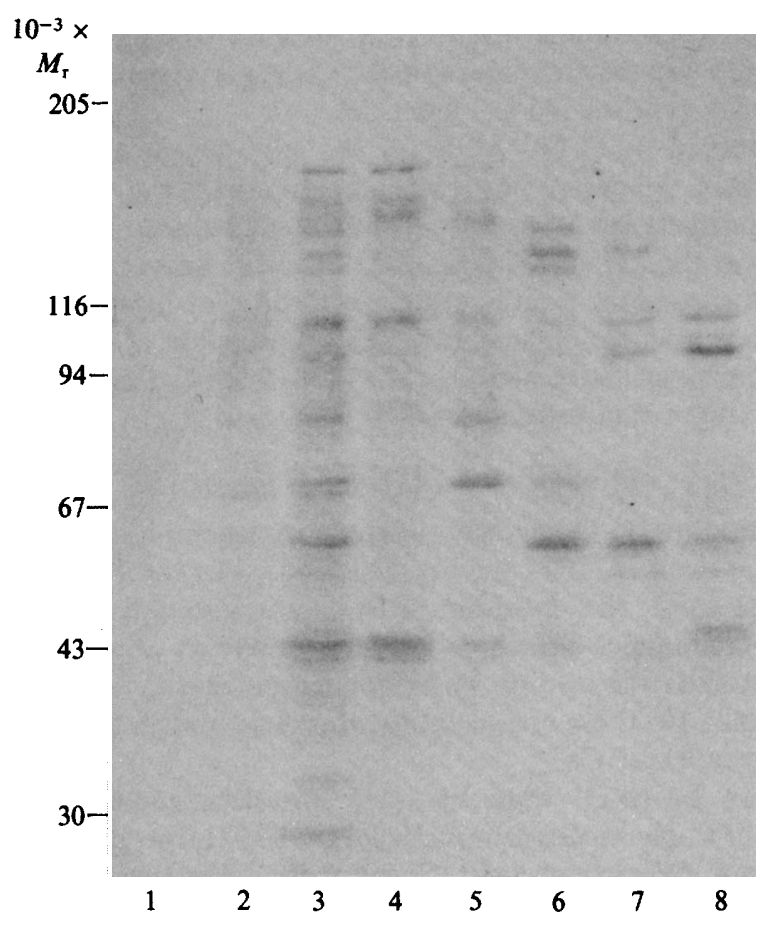

Fig. 3. Immunoblotting of the $\alpha$-amylase-pullulanase produced in $E$. coli. Samples were run on SDSPAGE (Laemmli, 1970) on a gel containing linear gradients of 4-16\% polyacrylamide and 0-18\% sucrose in the separating gel. Rabbit muscle myosin, $E$. coli $\beta$-galactosidase and Low Molecular Weight Calibration Kit proteins (Pharmacia) were used as standards. Transfer to a nitrocellulose filter and immunostaining was done essentially as described by Sarvas \& Nurminen (1985). Lanes [1-3, cell-free extracts from transformed JM109; 4-8, gel filtration fractions $(12.5 \mu \mathrm{l})$ from Fig. 2]: 1, unfractionated extract/pUC19 $(5 \mu \mathrm{l}) ; 2$, particulate fraction/pALK355 $(2.5 \mu \mathrm{l}) ; 3$, soluble fraction/pALK355 $(2.5 \mu \mathrm{l})$; 4 , fr. $179 ; 5$, fr. $184 ; 6$, fr. $191 ; 7$, fr. $196 ; 8$, fr. 199. 
The three enzyme peaks obtained by gel filtration (Fig. 2) were composed of different sets of $\alpha$-amylase-pullulanase polypeptides as judged by the intensities of the bands in the immunoblot in Fig. 3. Peak I contained a major band with $M_{\mathrm{r}}$ about 165000 , which was the highest value observed and probably represents full-length polypeptides. Peak II showed a triplet of bands around $M_{\mathrm{r}} 130000$ and peak III a doublet around $M_{\mathrm{r}} 100000$. The last value shows that the polypeptide chain can be broken at more than one-third of the way along its length without concomitant loss of activity. These $M_{\mathrm{r}}$ values together with those obtained by gel filtration suggest that the enzyme produced in $E$. coli is dimeric, as is the extracellular enzyme produced by the native host (Melasniemi, 1988). The biggest polypeptide produced by in vitro transcriptiontranslation from pALK 355 or its $6.2 \mathrm{~kb}$ insert alone using the Procaryotic DNA-Directed Translation Kit (Amersham) had an $M_{\mathrm{r}}$ some 20000 smaller than the $M_{\mathrm{r}}$ of the biggest polypeptide produced in vivo (not shown). The same polypeptide patterns were obtained by using either of the templates, confirming that an indigenous promoter was used for transcription in vitro.

Immunoblots of samples from the soluble and particulate fractions of the cell-free extracts (Fig. 3) showed that although the quantitative distribution of the $\alpha$-amylase-pullulanase polypeptides between these fractions was different, most of the immunoreactive polypeptides were present in both. The pattern of degenerate immunoreactive polypeptides seen by SDS-PAGE emerged as a whole at an early stage of culture and did not change during active growth (data not shown). This suggests that a prime cause of the degeneracy is either incomplete translation due to internal initiations or premature terminations, or rapid cleavage of newly synthesized polypeptides, or both. However, as culture was continued to the stationary phase and up to $4 \mathrm{~d}$, the bands at about $M_{\mathrm{r}} 43000,68000$ and 97000 became stronger whereas the one at about 57000 , together with all minor bands smaller than 94000 , became weaker. This suggests that a slower partial proteolysis of the various amylase molecules is superimposed on the process(es) causing degeneracy of the newly synthesized polypeptides.

The $M_{\mathrm{r}}$ values observed by SDS-PAGE for the subunits of two purified forms of the $\alpha$ amylase-pullulanase from the native host (Melasniemi, 1988) were higher than the highest $M_{\mathrm{r}}$ observed in Fig. 3. However, the $M_{\mathrm{r}}$ of the polypeptides produced by the native species may be considerably lower than the $M_{\mathrm{r}}$ values observed, since the enzyme showed several anomalous features and contains secondary modifications including, at least, carbohydrate. A carbohydrate-containing monomeric pullulanase $\left(M_{\mathrm{r}} 136500\right)$ capable of hydrolysing $\alpha-1,4$ glycosidic linkages has recently been purified by Saha et al. (1988) from $C$. thermohydrosulfuricum Z 21-109 by a procedure involving a lipase treatment.

\section{Thermal characteristics of the enzyme}

The effect of temperature on the activity of the enzyme produced in $E$. coli was assayed by using a cell-free extract from JM109 carrying pALK 355 . For the 15 min reaction times used in the presence of $10 \mathrm{mM}-\mathrm{Ca}^{2+}$, the optimum of the $\alpha$-amylase activity was at about $85^{\circ} \mathrm{C}$ and the optimum of the pullulanase activity some $5^{\circ} \mathrm{C}$ lower at about $80^{\circ} \mathrm{C}$. Raising the $\mathrm{Ca}^{2+}$ concentration did not shift the optima to higher temperatures, but if $\mathrm{Ca}^{2+}$ was omitted the optima were shifted some $10^{\circ} \mathrm{C}$ lower and at the same time both activities were reduced to about half of that in the presence of $\mathrm{Ca}^{2+}$.

A greater activation by $\mathrm{Mn}^{2+}$ than by $\mathrm{Ca}^{2+}$ has been reported for the $\alpha$-amylase and pullulanase activities of $C$. thermohydrosulfuricum DSM 567 (Antranikian et al., 1987). Maximal $\mathrm{Mn}^{2+}$ activation of the $E$. coli enzyme at $80{ }^{\circ} \mathrm{C}$ was observed at $2 \mathrm{mM}-\mathrm{MnCl}_{2}$, and was about $30 \%$ for the pullulanase activity and less for the $\alpha$-amylase activity, whereas activation by $\mathrm{Ca}^{2+}$ at the same temperature was about $290 \%$ for the pullulanase and about $210 \%$ for the $\alpha$-amylase activity. Over $90 \%$ of the maximal activation was observed with only $0.25 \mathrm{mM}-\mathrm{Ca}^{2+}$.

Thermal stability of the enzyme in the absence of substrate is presented in Table 1 . In the absence of $\mathrm{Ca}^{2+}$ the enzyme was stable at $65^{\circ} \mathrm{C}$, but was rapidly inactivated at $85^{\circ} \mathrm{C}$. In the presence of $10 \mathrm{mM}^{-\mathrm{Ca}^{2+}}$, however, more than $60 \%$ of the activity was still left after incubating the enzyme for $2 \mathrm{~h}$ at $85^{\circ} \mathrm{C}$. No heat activation similar to that reported for the amylase activities of strain DSM 567 (Antranikian et al., 1987) was evident in experiments with the solubilized $E$. 
Table 1. Heat stability of the $\alpha$-amylase-pullulanase produced in $E$. coli

The soluble fraction of a cell-free extract from JM109 carrying pALK355 was diluted with 100 mMsodium acetate $\mathrm{pH} 5.6$ to $2.1 \mathrm{kU}$ pullulanase activity, $0.64 \mathrm{kU} \alpha$-amylase activity and $0.8 \mathrm{mg}$ protein $\mathrm{ml}^{-1}$. Replicate samples were incubated at $55-95^{\circ} \mathrm{C}$ in the presence or absence of $10 \mathrm{mM}-\mathrm{CaCl}_{2}$ for 30 and $120 \mathrm{~min}$. The activity left was assayed as described in Methods using $50 \mu \mathrm{l}$ enzyme samples and pullulan as a substrate.

\begin{tabular}{|c|c|c|c|c|}
\hline \multirow{3}{*}{$\begin{array}{l}\text { Temp. } \\
\left({ }^{\circ} \mathrm{C}\right)\end{array}$} & \multicolumn{4}{|c|}{ Residual activity (\%) } \\
\hline & \multicolumn{2}{|c|}{$30 \mathrm{~min}$} & \multicolumn{2}{|c|}{$120 \mathrm{~min}$} \\
\hline & No $\mathrm{Ca}^{2+}$ & $10 \mathrm{mM}-\mathrm{Ca}^{2+}$ & No $\mathrm{Ca}^{2+}$ & $10 \mathrm{mM}-\mathrm{Ca}^{2+}$ \\
\hline 55 & 93 & 91 & 92 & 90 \\
\hline 60 & 93 & 90 & 94 & 91 \\
\hline 65 & 96 & 89 & 96 & 91 \\
\hline 70 & 94 & 89 & 93 & 91 \\
\hline 75 & 79 & 87 & 65 & 87 \\
\hline 80 & 46 & 84 & 15 & 72 \\
\hline 85 & 8.5 & 75 & 0.9 & 64 \\
\hline 90 & $1 \cdot 3$ & 58 & $0 \cdot 0$ & 22 \\
\hline 95 & 0.5 & 13 & $0 \cdot 1$ & 1.0 \\
\hline
\end{tabular}

coli enzyme, released by effective crushing of the cells. However, increased apparent activities were observed after heat treatment of enzyme entrapped (along with glucose-6-phosphate dehydrogenase) in the membranous matrix of incompletely lysed cells. Such samples showed almost $40 \%$ activation after incubation for $2 \mathrm{~h}$ at $70{ }^{\circ} \mathrm{C}$ in the absence of $\mathrm{Ca}^{2+}$ (which stabilizes lipid bilayers) and $25 \%$ activation in its presence, perhaps because of slow disintegration of the matrix at elevated temperatures. Some kind of a matrix effect might also explain the activation observed by Antranikian et al. (1987) if their enzyme, although extracellular, was not truly soluble.

Considering the marked degeneracy of the enzyme produced in $E$. coli, its thermal characteristics were surprisingly little affected as compared with the enzyme produced by the native host (Melasniemi, 1987 b) : the apparent temperature optimum was only some $5^{\circ} \mathrm{C}$ lower and the stability the same. Since an intracellular protein in $E$. coli can fairly safely be assumed to be non-glycosylated, the equal stabilities of the enzyme produced in either host seem to imply that the carbohydrate moiety of the $C$. thermohydrosulfuricum enzyme has no marked role in the thermostability of the enzyme.

The elucidation of the DNA sequence of the $\alpha$-amylase-pullulanase gene will bring more insight into this enzyme, e.g. reveal possible homology with known $\alpha$-amylases or pullulanases and show whether the enzyme and the satellite polypeptide are products of only one gene or of two co-regulated genes. The equimolarity and the intimate association of the enzyme and satellite polypeptides produced by $C$. thermohydrosulfuricum favour the idea that these two polypeptides arise in this organism as a consequence of a specific proteolytic cleavage. Despite the degeneracy of the polypeptides observed in $E$. coli, the cloned enzyme retained both its activities as well as its thermal characteristics. This invites further research to produce this novel enzyme by genetically engineered host systems.

We thank members of the Alko recombinant DNA group for useful discussions, Dr Paula Kristo for the synthetic oligonucleotides and Mrs Riitta Tarkiainen for technical assistance.

\section{REFERENCES}

Amundsen, S. K. \& Neville, M. E. (1979). Comparison of three procedures for isolating DNA from bacteria. Microbios 24, 29-39.

Antranikian, G., Zablowski, P. \& GotTschalk, G.
(1987). Conditions for the overproduction and excretion of thermostable $\alpha$-amylase and pullulanase from Clostridium thermohydrosulfuricum DSM 567. Applied Microbiology and Biotechnology 27, 75-81. 
Birnboim, H. C. \& Doly, J. (1979). A rapid alkaline extraction procedure for screening recombinant plasmid DNA. Nucleic Acids Research 7, 1513-1523.

Colmman, R. D., Yang, S.-S. \& McAlister, M. P. (1987). Cloning of the debranching-enzyme gene from Thermoanaerobium brockii into Escherichia coli and Bacillus subtilis. Journal of Bacteriology 169, 4302-4307.

Fogarty, W. M. \& Kelly, C. T. (1979). Starchdegrading enzymes of microbial origin. In Progress in Industrial Microbiology, vol. 15, pp. 87-150. Edited by M. J. Bull. Amsterdam: Elsevier.

HANAHAN, D. (1985). Techniques for transformation of E. coli. In DNA Cloning : a Practical Approach, vol. I, pp. 109-135. Edited by D. M. Glover. Oxford: IRL Press.

Holmes, D. S. \& Quigley, M. (1981). A rapid boiling method for the preparation of bacterial plasmids. Analytical Biochemistry 114, 193-197.

HuYNH, T. V., Young, R. A. \& Davis, R. W. (1985). Constructing and screening cDNA libraries in $\lambda \mathrm{gt} 10$ and $\lambda$ gt11. In DNA Cloning: a Practical Approach, vol. I, pp. 49-78. Edited by D. M. Glover. Oxford: IRL Press.

Kuriki, T., Okada, S. \& ImanaKa, T. (1988). New type of pullulanase from Bacillus stearothermophilus and molecular cloning and expression of the gene in Bacillus subtilis. Journal of Bacteriology 170, 15541559.

LAEMMLI, U. K. (1970). Cleavage of structural proteins during the assembly of the head of bacteriophage T4. Nature, London 227, 680-685.

MALAMY, M. H. \& HoReCKER, B. L. (1964). Release of alkaline phosphatase from cells of Escherichia coli upon lysozyme spheroplast formation. Biochemistry 3, 1889-1893.

Maniatis, T., Fritsch, E. F. \& SambrooK, J. (1982). Molecular Cloning: a Laboratory Manual. Cold Spring Harbor, NY: Cold Spring Harbor Laboratory.

MELASNIEMI, H. (1987a). Effect of carbon source on production of thermostable $\alpha$-amylase, pullulanase and $\alpha$-glucosidase by Clostridium thermohydrosulfuricum. Journal of General Microbiology 133, 883890.

MELASNIEMI, H. (1987b). Characterization of $\alpha$-amylase and pullulanase activities of Clostridium thermohydrosulfuricum. Evidence for a novel thermostable amylase. Biochemical Journal 246, 193-197.

MELASNIEMI, H. (1988). Purification and some properties of the extracellular $\alpha$-amylase-pullulanase produced by Clostridium thermohydrosulfuricum. Biochemical Journal 250, 813-818.
Miyada, C. G. \& Wallace, R. B. (1987). Oligonucleotide hybridization techniques. Methods in Enzymology 154, 94-107.

NeU, H. C. \& HePpel, L. A. (1965). The release of enzymes from Escherichia coli by osmotic shock and during formation of spheroplasts. Journal of Biological Chemistry 240, 3685-3692.

Plant, A. R., Clemens, R. M., Morgan, H. W. \& DANiEl, R. M. (1987). Active-site- and substratespecificity of Thermoanaerobium Tok6-B1 pullulanase. Biochemical Journal 246, 537-541.

Saha, B. C., Mathupala, S. P. \& Zeikus, J. G. (1988). Purification and characterization of a highly thermostable novel pullulanase from Clostridium thermohydrosulfuricum. Biochemical Journal 252, 343-348.

Sarvas, M. \& Nurminen, M. (1985). Polyacrylamide gel electrophoretic analysis of cell envelope proteins. In Enterobacterial Surface Antigens: Methods for Molecular Characterisation, pp. 123-137. Edited by T. K. Korhonen, E. A. Dawes \& P. H. Mäkelä. Amsterdam: Elsevier.

Shimizu, M., Kanno, M., Tamura, M. \& Suekane, M. (1978). Purification and some properties of a novel $\alpha$ amylase produced by a strain of Thermoactinomyces vulgaris. Agricultural and Biological Chemistry 42 , 1681-1688.

Smit, J., Kamio, Y. \& Nikaido, H. (1975). Outer membrane of Salmonella typhimurium: chemical analysis and freeze-fracture studies with lipopolysaccharide mutants. Journal of Bacteriology 124, 942958.

SuzuKI, Y. \& ImaI, T. (1985). Bacillus stearothermophilus KP 1064 pullulan hydrolase. Its assignment to a unique type of maltogenic $\alpha$-amylase but neither pullulanase nor isopullulanase. Applied Microbiology and Biotechnology 21, 20-26.

Suzuki, Y., Nagayama, T., Nakano, H. \& Oshi, K. (1987). Purification and characterization of a maltogenic $\alpha$-amylase I and maltogenic $\alpha$-amylase II capable of cleaving $\alpha-1,6$-bonds in amylopectin. Starch 39, 211-214.

TAKASAKI, Y. (1987). Pullulanase-amylase complex enzyme from Bacillus subtilis. Agricultural and Biological Chemistry 51, 9-16.

WIEGEL, J., LJUNGDAHL, L. G. \& Rawson, J. R. (1979). Isolation from soil and properties of the extreme thermophile Clostridium thermohydrosulfuricum. Journal of Bacteriology 139, 800-810.

Yanisch-Perron, C., Vieira, J. \& Messing, J. (1985) Improved M13 phage cloning vectors and host strains: nucleotide sequences of the M13mp18 and pUC19 vectors. Gene 33, 103-119. 